Zabytkoznawstwo i Konserwatorstwo XLVI, Toruń 2015

Halina Turska

Zakład Historii Sztuki Średniowiecznej i Nowożytnej

\title{
Średniowieczna ikonografia św. Weroniki - treści ideowe i funkcje przedstawienia
}

Dunktem wyjścia dla analizy ikonografii św. Weroniki jest jej wizerunek 1 w bazylice katedralnej św. Janów w Toruniu.

Malowidło ścienne przedstawiające postać św. Weroniki trzymającej chustę z wizerunkiem Chrystusa - Veraicon [il. $1^{1}$ ] znajduje się na wschodniej ścianie nawy południowej, po prawej stronie prezbiterium Katedry. Wśród nielicznych i zachowanych tylko fragmentarycznie malowideł ściennych w części nawowej kościoła św. Janów wyróżnia się swoją oryginalnością. Zwraca uwage fakt umieszczenia malowidła bardzo wysoko. Datowane jest ono na trzecia tercję XV wieku po podwyższeniu części nawowej. Wydaje się, iż zarówno lokalizacja, treści i funkcja mogą być spójne i nasycone przesłaniem skierowanym do ówczesnych wiernych. Próba wyjaśnienia tego przesłania wymaga analizy typu ikonograficznego w kontekście czasu i okoliczności powstania - religijności mieszkańców ówczesnego Torunia i wydarzeń historycznych.

Artykuł nie jest monografią ikonografii św. Weroniki, dotyczy przede wszystkim analizy wariantów pokrewnych obrazowi z Torunia.

1 Malarstwo gotyckie w Polsce, Katalog zabytków, red. A. S. Labuda, K. Secomska, mce 2004, t. 2, cz. 3 - Katalog zabytków, s. 99-101; Opus temporis: torunskiej katedry historia najnowsza: Prace konserwatorskie i restauratorskie w latach 2000-2013, red. nauk. K. Kluczwajd, M. Rumiński, Toruń 2013, s. 134, il. 27 na s. 134. 
Według informacji konserwatora ${ }^{2}$ wizerunek był bardzo zniszczony, twarze przetarte, widoczny mocny kontur, partie barwne malowane „płasko", bez modelunku.

Próbę analizy ikonografii można podjąć obecnie, ponieważ dokonana konserwacja uwidoczniła wiele nieczytelnych dotąd szczegółów. Być może dlatego w literaturze nie podjęto dotąd próby analizy ikonografii i treści ideowych dzieła. Konserwacja umożliwiła jednoznaczne zidentyfikowanie postaci trzymającej chustę jako kobiety, ubranej w czerwoną suknię i niebieski płaszcz, podwikę i maforion.

Święta Weronika trzyma dużych rozmiarów chustę - element dominujący w kompozycji. Chusta w kształcie zbliżonym do prostokąta opada równolegle zaznaczonymi miseczkowatymi fałdami. Po obu stronach flankują tkaninę trapezoidalne opadające pionowo fałdy. W centrum chusty znajduje się dużych rozmiarów ujęte frontalnie oblicze Chrystusa. Twarz (rysy prawie niewidoczne) okalaja po obu stronach włosy układające się u dołu w dwa zawinięte koncentrycznie pukle. Trójkątna, rozdzielająca się na dwie części broda zakończona jest ujętymi w podobny sposób koncentrycznymi puklami. Oblicze ujęte jest w okragły nimbus cruciferis (stylizowane lilie), brak korony cierniowej. Małych rozmiarów postać Weroniki jest prawie niewidoczna spoza trzymanej przez nią w obu rękach chusty. Widoczna jest tylko głowa zwrócona nieco na lewo, szyja i fragmentarycznie ramiona. Weronika trzyma chustę w charakterystyczny sposób, ujmując tkaninę całymi dłońmi. Powyżej dłoni Świętej tkanina chusty układa się również w szczególny sposób - tworzy trójkaty - charakterystyczny szczegół tego wariantu ikonograficznego [il. 1].

Dzięki powyższym ustaleniom możliwe jest analizowanie w artykule typu ikonograficznego wizerunku oraz jego treści i funkcje w przestrzeni kościoła, możliwe jest podjęcie próby odpowiedzi na pytanie, dlaczego w Toruniu sięgnięto po tego typu wizerunek Świętej, niewymienianej w Biblii.

2 Informacja od Izabelli Brzostowskiej, autorki dokumentacji prac konserwatorskich w katedrze pw. św. Jana Chrzciciela i św. Jana Ewangelisty w Toruniu, wykonanych przez Pracownię Konserwacji Malarstwa, Rzeźby i Architektury RESTAURO Sp. z o.o. 


\section{Ikonografia, treści ideowe, funkcja przedstawienia}

Niehistoryczna, tajemnicza postać właścicielki chusty z obliczem Chrystusa identyfikowana była z kobietami z Pisma Świętego, występującymi w tekstach historycznych oraz apokryficznych. U źródeł ikonografii św. Weroniki stoi przedstawienie Oblicza Chrystusa, należące do tzw. nie ręką ludzką

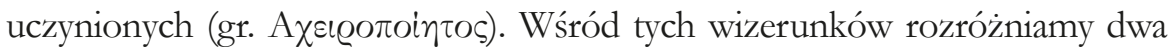
typy ikonograficzne - starszy, związany z tradycją Kościoła Wschodniego - Mandylion i młodszy związany z tradycją Kościoła Zachodniego - Veraicon ${ }^{3}$. Św. Weronika przedstawiana bywa w ikonografii jako „właścicielka" obu typów wizerunku i oba są jej atrybutami, zatem oba typy należy uwzględnić w analizie.

\section{Historia relikwii na Wschodzie}

W literaturze - Kroniki Ewagriusza - po raz pierwszy wspomniano Mandylion już w VI wieku. Znajduje się tam informacja, w jaki sposób on po-

3 Na temat acheiropietos-Mandylion Veraicon: H. Belting, Das Bild und sein Publikum im Mittelalter, Berlin 1981; idem, Obraz i kult. Historia obrazu przed epoka satuki, tłum. T. Zatorski, Gdańsk 2010; M. Büchsel, Die Entstehung des Christus porträts.Bildarchäologie statt Bildhypnose, Meinz am Rhein 2003; Veronika, [Johannes H. Emminghaus], Lexikon für Theologie und Kirche, hrsg. J. Höfer, K. Rahner, Freiburg im Breisgau 1965, Bd. 10, s. 728-729; Veronika, [Johannes H. Emminghaus], Lexikon der christlichen Ikonographie, hrsg. Wolfgang Braunfels, Rom, Freiburg 1976, Bd. 8, s. 543-544; A. Grabar, La Sainte Face de Laon. Le mandylion dans l' art. Orthodoxe, Praha 1931; Antlitz, heiliges [Adolf Katzenellenbogen], Reallexikon zur deutschen Kunstgeschichte, red. O. Schmitt, Bd. 1, Stuttgart 1937, s. 732-742; J. J. Kopeć, Męka Panska w religijnej kulturze polskiego średniowiecza, "Textus et Studia", t. 3, Warszawa 1975; K. Künstle, Ikonographie der christlichen Kunst, t. 1, cz. 2, Freiburg im Breisgau 1928, s. 443-444, s. 589-592; G. Morello, G. Wolf, Il volto di Cristo (katalog wystawy), Milano 2000, H. Turska, Veraicon w średniowiecznym Toruniu, „AUNC. Zabytkoznawstwo i Konserwatorstwo" 45, Toruń 2013, s. 57-73; J. Wilson, Całun Turyński, t. 1, tłum. A. Polkowski, mce 1986. 
wstał - Chrystus sam przyłożył chustę do twarzy i pozostało odbicie, kiedy powstał - w czasie publicznej działalności Chrystusa przed Pasją oraz że właścicielem wizerunku był król Edessy Abgar.

W tych samych Kronikach wspomina się o cudach, jakie czyniła ta relikwia. Jednym z nich było uzdrowienie króla Abgara. Kroniki podają, iż w pewnym okresie Chusta z Edessy znajdowała się w niszy nad bramą miejską w Edessie. Zamurowana, cudownie odkryta ochroniła miasto przed Persami, spełniając funkcję palladionu. Dalsze informacje podają kroniki z X w., według których relikwia - nazywana Mandylionem - od 944 znajdowała się w Konstantynopolu i otaczana była wielkim kultem. Charakterystyczne dla ikonografii Mandylionu było Chwalebne Oblicze Chrystusa, bez oznak męki, ([il. 2 A] Ikona, Mandylion z Nowgorodu, k. XII w. $)^{4}$. W 1204 roku, po zdobyciu Konstantynopola przez łacinników ślad po relikwii ginie. Nie zmienia to faktu, iż prawo do posiadania tej relikwii rościł sobie Rzym, Paryż, Genua i inne miasta.

\section{Historia relikwii na Zachodzie}

Najstarsze informacje o relikwii chusty znajdującej się w Rzymie są bardzo enigmatyczne, a na pewno była ona w cieniu Mandylionu. W opisie bazyliki św. Piotra w Rzymie (Historia basilicae Vaticanae antiguae, Petrus Mallius ok. 1160) znajduje się informacja o chuście „sudarium”, na której przed męka Chrystus odcisnął swoje oblicze. Chustę zwano Veronica. Ok. 1290 r. Gerwazy z Tilbury wspomina o jakimś obrazie widocznym na relikwii chusty, „który przybył do Rzymu wraz z niejaką Veronika, kobietą nikomu nie znaną" (Otia Imperialia, ok.1200 r. - autor powołuje się na legendy o Piłacie) ${ }^{5}$.

W czasie pontyfikatu Celestyna III (1191-1198) relikwia umieszczona była w górnej części cyborium Bazyliki św. Piotra w Rzymie ${ }^{6}$. Znamien-

4 Problemy treści ideowych związanych z Mandylionem zob. H. Turska, Veraicon w średniowiecznym Toruniu s. 60, przypis 8; Mandylion z Nowgorodu omawia - Belting 1981, s. $180-183$, il. 68,69 .

5 H. Belting, Obraz $i$ kult..., s. 610-611.

${ }^{6}$ Ibidem, s. 253. 
ne, że od początku XIII wieku, kiedy ginie ślad po wschodnim Mandylionie z Konstantynopola, można obserwować coraz liczniejsze informacje i dowody wzrastającego kultu rzymskiej relikwii - procesje, modlitwy, hymny i odpusty. Innocenty III (1198-1218) ustanowił nabożeństwo i procesję z relikwią Chusty z Bazyliki św. Piotra do Szpitala św. Ducha. Była ona praktykowana do pontyfikatu Klemensa V (1305-1314). Fundamentalną zmianą statusu Chusty wśród innych relikwii było wydarzenie w czasie jednej z procesji w 1216 roku. Wizerunek miał wówczas odwrócić się o 180 stopni, co potraktowano jako cud poświadczający prawdziwość i rangę relikwii ${ }^{7}$. Pierwszy odpust związany z relikwią ustanowił Innocenty III. Papież Bonifacy VIII w końcu XIII w. ustanowił dalsze odpusty związane z modlitwa przed oryginałem lub kopią św. Oblicza z Rzymu. Wizerunek był wykorzystywany w dewocji prywatnej, zalecano specjalną modlitwę przed św. Obliczem z Rzymu. W XVI wieku relikwia zaginęła, choć pojawiały się informacje o jej rzekomym istnieniu w różnych miejscach. Opisane wyżej praktyki sprzyjały zarówno pielgrzymkom do rzymskiej Relikwii, jak i rozpowszechnianiu wizerunku. Jego kult stopniowo wypiera wschodni Mandylion. W 1287 roku pokazuje się rzymską relikwię syryjskiemu mnichowi jako odcisk twarzy Chrystusa na chuście, który był w posiadaniu Abgara. Pątnictwo do Rzymu było w tym czasie ruchem masowym, jednym z jego celów było odwiedzenie oryginału obrazu. Jego repliki zabierano ze sobą w różnej postaci - np. plakietek pątniczych przyszywanych do odzieży. Tzw. Pictores Veronicorum mieli monopol na masowe wytwarzanie takich wizerunków i ich rozpowszechnianie.

Legendarna Weronika, na Zachodzie uważana za pierwotną właścicielkę wizerunku Chrystusa stała się wkrótce w powszechnej świadomości samodzielna postacią.

Legendarna historia Weroniki ${ }^{8}$, kobiety w kontekście wizerunku Chrystusa, powstawała stopniowo i można wyróżnić kilka etapów jej kształ-

H. Beltin, Das Bild..., s. 35; idem, Obraz i kult..., s. 612-613.

$8 \mathrm{Na}$ temat św. Weroniki H. Belting, Das Bild..., idem, Obraz $i$ kult...; Emminghaus Lexikon für..., s. 728-729; idem, Lexikon der..., s. 543-544; A. Grabar, op.cit., G. Kaftal, Iconography of the saints in the painting of North East Italy, Florence 1978; A. Katzenellenbogen op.cit., s. 732-742; J. J. Kopeć, op.cit.; K. Künstle, op.cit., t. 1, cz. 2, 1928, s. 443-444, s. 589-592; G. Morello, G. Wolf, op.cit.; L. Reau, Iconogrphie de l art. Chretien, Iconagrphie 
towania. Najwcześniejsze warianty opowiadania powstawały od VI do VII wieku poprzez połączenie tekstów o charakterze historycznym, apokryfów i legend. Wśród tych tekstów wskazać należy Historie Kościoła autorstwa Euzebiusza. Wspomina on o kobiecie z miasta Paneas (Cezarea Filipowa) o imieniu Hermoroisa. Miała ona być uleczona przez Chrystusa i z wdzięczności ustawić brązowy posag Chrystusa dokonującego uzdrowienia. W apokryficznych Aktach Piłata wspomina się o uleczeniu cierpiącej na krwotok kobiety o imieniu Berenika. Miała ona posiadać cudowny obraz Jezusa malowany na chuście. W XI-wiecznej niemieckiej wersji legendy o Piłacie opisany jest cudowny sposób, w jaki powstał wizerunek Chrystusa. Kobieta - spotkała Pana, który przycisnął płótno do twarzy. W ten sposób utrwalone zostały rysy Chrystusa. Ten sam tekst informuje, iż tym wizerunkiem uleczony został cesarz Tyberiusz. Ta wersja opowieści została spopularyzowana w XIII wieku przez Złotą Legendę Jakuba de Voragine’a. Treść legend zawartych w Złotej Legendzie nie tylko kształtowała powszechną świadomość ówczesnych wiernych, ale także często stała u źródeł przedstawień plastycznych w średniowieczu. Wszystkie wymienione wyżej wersje legendy o kobiecie posiadającej obraz Chrystusa wskazują że chodzi o wizerunek Chrystusa przed Pasją. Legendy powyższe tworza przekonanie, iż pierwotną właścicielką „wizerunku nie ręką ludzką uczynionego” była Weronika, a nie Abgar.

Fundamentalna zmiana w przekazach pisemnych następuje ok. $1300 \mathrm{r}$. w Biblii Rogera van Argenteuil. W Biblii tej chustę i św. Weronikę włączono do historii Męki Pańskiej. Weronika spotyka Chrystusa w czasie drogi krzyżowej i podaje Zbawicielowi do obtarcia oblicza chustę - na której pozostało odbicie twarzy Boga. Ta wersja opowieści wpływa decydująco na ideowe treści przekazu, który po raz pierwszy łączy zarówno Weronikę, jak i wizerunek na chuście z okresem cierpienia i poniżenia Chrystusa. Ma to decydujący wpływ na kształtowanie w sztuce wizerunku Veraiconu. Zwraca uwagę wierzących na Pasję Chrystusa, co jest rysem dojrzałego średniowiecza. Św. Weronika podająca chustę Chrystusowi staje się niejako wzorem każdego wyznawcy, który może i powinien podążać jej śladem. Jednocze-

des Saint Paris 1959, t. III, cz. 3, s. 1314-1317; J. deVoragine, Złota Legenda, tłum. J. Pleziowa, wybrał M. Plezia, Warszawa 2000, s. 209-211. 
śnie gest współodczucia wnosi do brutalnej opowieści o Drodze Krzyżowej akcent nadziei. W wyniku długotrwałego procesu w sztuce wykształca się typ wizerunku Chrystusa z obliczem naznaczonym cierpieniem, z koroną cierniową ([il. 2B.] Veraicon z Legnicy, ok. 1450)․

Postać św. Weroniki w licznie wystawianych w średniowieczu misteriach określano również jako handlarkę płótnem. Służyło to wyjaśnieniu powodu, dla którego posiadała płócienną chustę. Cudownie odbity wizerunek Chrystusa miał rzekomo niewidzącej Weronice pomóc odzyskać wzrok. Według legendy gaskońskiej Weronika była także apostołem w Medoc (Francja). Relikwie św. Weroniki przechowywane w kościele Notre Dame-de-la-findes-Terres przyciagały tłumy pielgrzymów. Dla niniejszych rozważań istotne jest to, iż w krajach, w których obecny był kult Veraiconu, łączono go integralnie z postacią św. Weroniki. Poświadczała ona prawdziwość relikwii z Rzymu. Wierzono, iż każdy, kto patrzy na wizerunek, uwolni się od niespodziewanej śmierci. Św. Weronika była, podobnie jak św. Barbara i św. Krzysztof, przywoływana w modlitwach o ochronę przed nagła śmiercia bez wyspowiadania. W związku z tym często przedstawienia św. Weroniki pojawiały się w Księgach Godzin. Do popularności św. Weroniki przyczyniły się te cechy, które przyjęły ją za swoja patronkę - np. handlarzy tkanin. We Francji rozporządzenie króla Karola VI z 1381 r. pozwoliło tymże handlarzom tkanin założyć bractwo pod patronatem św. Weroniki w kościele pw. św. Eustachego w Paryżu. Modliły się również do niej powszechnie bieliźniarki i praczki z powodu białej tkaniny, na której utrwalił się wizerunek Zbawiciela ${ }^{10}$.

Apogeum kultu św. Weroniki przypadło na dojrzałe średniowiecze i zanikało po Soborze Trydenckim.

W ikonografii już od XIV w. znany jest wizerunek stojącej frontalnie kobiety trzymającej w uniesionych rękach rozpostartą chustę z wizerunkiem Chrystusa (do najwcześniejszych przykładów zalicza się kamienną rzeźbę [il. 3] (rzeźba zamówiona ok. 1310 r. dla kolegiaty Notre-Dame d'Ecouis,

9 A. Ziomecka, Sztuka na Ślasku, Katalog źbiorón, Muzeum Narodowe we Wrocławiu, Wrocław 2003, s. 261-262, kat. 47, il. 47

10 Zobacz przypis 8; na temat bractwa handlarzy tkanin - Reau 1959, s. 1315. 
departament Eure $)^{11}$. Szczególną rolę w rozpowszechnianiu tego rodzaju wizerunku przypisuje się Kolońskiemu Mistrzowi św. Weroniki (św. Weronika trzymająca Chustę, malowana tablica ok. 1420, pochodzi z kościoła St. Severin - służyła prawdopodobnie za drzwiczki tabernakulum.) [il. 4]) ${ }^{12}$. Czasami, odnosząc się do rzekomych syryjskich źródeł św. Weroniki, przedstawiano ja w turbanie. W późniejszym okresie ukazywana bywa razem z reprezentującymi Kościół św.św. Piotrem i Pawłem (św. Weronika pomiedzy św. Piotrem i Pawtem, A. Durer, grafika, 151013). Jako odrębną kategorię należy traktować sceny, na których św. Weronika przedstawiona jest w kontekście drogi krzyżowej (Niesienie krzyża, Droga krzyżowa, Martin Schongauer, $\left.1496^{14}\right)$. Tego typu kontekst nie występuje w Toruniu, dlatego też biorę pod uwagę wyłącznie samodzielne przedstawienia Świętej.

\section{Ikonografia św. Weroniki}

W ikonografii już od XIV w. wykształcił się typ ikonograficzny stojącej frontalnie kobiety trzymającej w uniesionych rękach rozpostartą chustę z wizerunkiem Chrystusa [il. 3]. Wspomniana wyżej rzeźba zamówiona ok. 1310 r. dla kolegiaty Notre-Dame d'Ecouis. Rzeźba ukazuje stojąca frontalnie w całej postaci kobietę, ubraną w płaszcz, suknię oraz maforion i podwikę na głowie. W uniesionych na wysokości piersi dłoniach trzyma chustę ze słabo widocznym wizerunkiem twarzy. W płytkim reliefie artysta bardzo niewyraźnie zaznaczył rysy oblicza (oczy, usta, nos) i trudno połaczyć ten wizerunek z jednym z typów ikonograficznych wizerunku Chrystusa. Na pewno stwierdzić można brak korony cierniowej. Paradoksalnie słabo widoczne rysy na chuście w sposób aluzyjny dobrze ilustruja główny przekaz legendy o św. Weronice, mówiący o odbitym na chuście obliczu Chrystusa. Podkreślić należy, iż w tym wczesnym typie ikonograficznym

11 G. Morello, G. Wolf, op.cit., il. 2 na s. 105; L. Reau, op.cit., s. 1316, il.79 na s. 1313.

12 M. Büchsel, op.cit., s. 164, il. 62; Emminghaus, Lexikon der..., s. 543-544; G. Morello, G. Wolf, op.cit., s. 107, il. 4.

13 G. Morello, G. Wolf, op.cit., kat. IV.46, il. s. 154.

14 Ibidem, s. 110, il. 5. 
wzajemne proporcje postaci Weroniki i chusty (chusta zajmuje ok. ${ }^{1} /{ }_{4}$ postaci św. Weroniki) cechuje swoisty realizm, a postać Świętej jest dobrze widoczna. Również z terenu Francji pochodzi rzeźba (Museum w Dijon, datowana na XIV w.), która w typie ikonograficznym nawiazzuje do wyżej opisanej. Podobieństwo dotyczy szczególnie stroju (suknia, maforion i podwika na głowie) [il. $11 \mathrm{~A}]^{15}$ oraz wzajemnych proporcji postaci, powielajacych realistyczny schemat, opisany wyżej. Istotną różnicę zawiera natomiast relief z wizerunkiem Chrystusa. Na omawianym zabytku z Dijon już bardzo wyraźnie zaznaczono rysy twarzy Zbawiciela. Typ ikonograficzny tego wizerunku nawiązuje do pozbawionego oznak męki Mandylionu. Do wyżej opisywanego typu ikonograficznego św. Weroniki zaliczyć można postać namalowana na tablicy ze szkoły Tomassa da Modena, ok. 1350 (Treviso, S. Lucia, [il. 11B] $)^{16}$. Również na tym obrazie trzymane przez Weronikę oblicze Chrystusa z nimbem wokół głowy, bez korony cierniowej i oznak męki jest typem Mandylionu. Należy podkreślić dominująca sylwetkę św. Weroniki w stosunku do małych rozmiarów chusty.

Do wczesnych XV-wiecznych wizerunków św. Weroniki zalicza się wspomniany już namalowany przez Mistrza św. Weroniki obraz datowany ok. 1420 (il. 4) ${ }^{17}$. Obraz przedstawia stojącą frontalnie Święta, która w wysoko uniesionych dłoniach trzyma dużych rozmiarów chustę. U dołu, po obu stronach, symetrycznie ukazano po trzy małe anioły czytające z księgi i banderoli. Omawiane przedstawienie powiela schemat ubioru Świętej (płaszcz, maforion, podwika). Fundamentalna zmiana dotyczy chusty z wizerunkiem Chrystusa. Podkreślić należy, iż Mistrz zastosował nowy typ ikonograficzny Oblicza Chrystusa. Na głowie Zbawiciela artysta umieścił koronę cierniową, spod której spływają krople krwi i potu. Nieco uniesione brwi, półprzymknięte powieki, cienie pod oczyma, bruzdy wokół ust wyraźnie wizualizuja cierpienie na twarzy Chrystusa. Artysta przedstawił pasyjne oblicze Zbawiciela. Mistrz nawiązał w ten sposób bezpośrednio do

15 François de Dijon, Sainte Véronique, pierre avec des traces de polychromie. Bourgogne milieu du XIV eme siècle. Musée des beaux arts de Dijon (Côte d'Or, France). dostęp 1.02.2015. http://commons.wikimedia.org/wiki/File:Sainte_V\%C3\%A9ronique-MBA_Dijon.jpg.

16 G. Kaftal, op.cit., s. 1045-1046, il. 1346.

17 Patrz przypis 12. 
nowej wersji legendy o św. Weronice (pozyskanie odbicia twarzy Chrystusa w czasie Jego Drogi Krzyżowej). Podkreślić należy fundamentalną zmianę wzajemnych proporcji postaci św. Weroniki i chusty (chusta stanowi ok. $3 /{ }_{4}$ postaci Weroniki i zakrywa prawie cała postać Świętej - od piersi w dół). Ten nowy typ ikonograficzny sugeruje nowe treści ideowe - zwraca uwagę na Pasję Chrystusa i przesuwa akcenty - z postaci Świętej na dominujący wizerunek Chrystusa, który staje się głównym tematem.

Do tego typu ikonograficznego zaliczyć można wspomniane niżej przedstawienia. Zasadniczym kryterium kwalifikującym przedstawienia św. Weroniki do tej grupy ikonograficznej sa wzajemne proporcje chusty i postaci św. Weroniki (przedmiotem analizy sa przedstawienia stojącej frontalnie świętej).

Kościół klasztorny św. Mikołaja, Francja, płaskorzeźba wspornik (Brou, pocz. XVI w. [il. 5] $)^{18}$. Postać Świętej Weroniki jest prawie niewidoczna spoza trzymanej przez nia chusty, a fragmentarycznie widoczne jej ramiona i głowa pozwalają zaliczyć jej ubiór do opisywanego wyżej schematu. Palcem prawej ręki Święta wskazuje oblicze Zbawiciela - bez korony cierniowej, typu chwalebnego.

Kościół św. Mikołaja w Marktbreit, sakrarium ścienne, płaskorzeźba, ok. 1400 (il. 6) ${ }^{19}$. Postać Świętej pojawia się jako dekoracja w wimpergowym zwieńczeniu sakrarium ściennego. Wizerunek Świętej nawiązuje do opisywanego wyżej schematu, nowościa jest trapezoidalny kształt chusty z obliczem Chrystusa bez korony cierniowej.

Susz, kościół farny, malowidło ścienne nad wejściem do zakrystii, ok. 1400 (il. 7) ${ }^{20}$. Postać św. Weroniki osadzona została w polu tympanonu wyznaczonego przez namalowany powyżej wyjścia do zakrystii łuk ostry. Po lewej stronie kompozycji umieszczono w pozie adorującej mała postać fundatora. Widoczne spoza chusty fragmenty postaci pozwalają ustalić

\footnotetext{
18 Kościół św. Mikołaja, Francja, http://commons.wikimedia.org/wiki/File:Corbel_ Brou_3.jpg\#mediaviewer/File:Corbel_Brou_3.jpg, Remi Mathis, dostęp 21.01.2015.

19 http://commons.wikimedia.org/wiki/Category:St._Nikolai_\%28Marktbreit\%29\#/media/File:Marktbreit_St_Nikolai_Wandtabernakel.jpg, Andreas Praefcke, dostęp 19.01.2015.

20 J. Domasłowski, Pomorze Wschodnie, w: Gotyckie malarstwo ścienne w Polsce, red. A. Karłowska-Kamzowa, Poznań 1984, s. 121-162, s. 128, il. 183, UAM, Seria „Historia Sztuki”, nr 17.
} 
ubiór jako powielający opisany schemat. Podobieństwem do opisanego wyżej reliefu w Marktbreit jest trapezoidalny kształt chusty.

Kraków, kościół Bożego Ciała, witraż 1420-1430 (il. 8A)²1. Mimo trudności z dokładnym odczytaniem ikonografii stwierdzić można, iż wizerunek Świętej powiela opisywany wyżej schemat ubioru, oblicze Chrystusa nie ma korony cierniowej, a nimb krzyżowy tworzą stylizowane lilie.

Watykan, Muzeum Watykańskie, plakietka pielgrzymia, z wizerunkiem św. Weroniki, 2 poł. XV w. (brąz $55 \times 99 \mathrm{~mm}$ ) (il. 9) ${ }^{22}$. Postać Świętej powiela schemat $\mathrm{w}$ zakresie ubioru. W odróżnieniu od dotąd opisanych przykładów głowa Świętej zwrócona jest nieco na prawo. Twarz Zbawiciela na chuście otoczona nimbem krzyżowym bez korony cierniowej.

Orneta, kościół farny, malowidło ścienne, 3 ćw. XV w. (il. 8B) ${ }^{23}$. Malowidło w dolnej części zniszczone. Zachowany fragment pozwala zaliczyć ukazaną tu święta Weronikę do omawianej grupy ikonograficznej. Chusta zakrywa Świętą tak, iż nie widać dłoni, tkaninę trzymaja po bokach dwa małe anioły (Anioły Mszy). Ubiór powiela opisywany schemat, oblicze Chrystusa przedstawia typ chwalebny.

Miniatura z Kroniki Świata Schedla 1493rok [il. 10] ${ }^{24}$. Strój wyróżnia się nakryciem głowy - rodzajem strojnego turbana, spod którego spływaja na plecy włosy. Artysta, podobnie jak Mistrz św. Weroniki przedstawił na chuście pasyjne oblicze Zbawiciela. Duża zielona korona cierniowa, zmarszczki na czole, bruzdy pod oczyma i wokół ust wizualizuja cierpienie Pasji.

Można także wskazać dalsze przykłady zastosowania tego typu ikonografii ${ }^{25}$.

21 Malarstwo gotyckie w Polsce, Katalog zabytków 2004, t. 2, cz. 3, s. 129-131; Katalog zabytków sztuki w Polsce, t. IV, Miasto Kraków, cz. 4, red. J. Samek, J. Rejduch-Samkowa, Warszawa 1987 , s. 55 , il. 9256.

22 G. Morello, G. Wolf, op.cit., Kat nr IV.12, s. 179, il. na s. 124.

23 J. Domasłowski, op.cit., s. 121-162, il. 205.

${ }_{24}$ Kronika Świata Schedla http://commons.wikimedia.org/wiki/File:Nuremberg_chronicles_f_097r_1.png, dostęp 15.02.2015.

25 Tryptyk relikwiarzowy-Trptychonreliguiar, ok. poł. XV w. Danzig, Marienkirche, zob. J. Braun, Die Reliquiare des christlichen Kultes und ibre Entwicklung, Freiburg im Breisgau 1940, s. 630 , il. 240. 


\section{Analiza.}

\section{Treści ideowe i funkcje}

Analiza zgromadzonego materiału zabytkowego pozwala stwierdzić dużą różnorodność typów ikonograficznych wizerunków św. Weroniki. Dotyczy to w mniejszym stopniu wizerunku samej Świętej, w większym Chusty z Obliczem Chrystusa. Świętą ukazywano dość konsekwentnie jako niewiastę odzianą w suknię, płaszcz, z głową okrytą maforionem i podwika. Ubiór taki nie był jednak obligatoryjny - można wskazać liczne odstępstwa. Zdarzają się przedstawienia Świętej w turbanie na głowie [il. 10] lub odzianej w modną suknię współczesnej przestawieniu damy. Zwraca również uwagę szczególny brak konsekwencji co do stosowania typu ikonograficznego wizerunku Chrystusa na Chuście. Artyści wykorzystywali zarówno wizerunek chwalebny - Mandylion, jak i pasyjny - Veraicon. Brak konsekwencji jest adekwatny do historii wizerunku Zbawiciela „nie ręką ludzką uczynionego". Wypieranie wschodniego Mandylionu i zastępowanie go zachodnim, pasyjnym Veraiconem znajduje swoje odbicie w ikonografii św. Weroniki. Długotrwały proces wykształcania się zachodniego, pasyjnego obrazu powodował, że stosunkowo rzadko, zasadniczo począwszy od połowy XV w., ukazywano Świętą z obliczem umęczonego Zbawiciela. Ze względu na wspomnianą wyżej niekonsekwencję wykorzystywania typu wizerunku Chrystusa w rękach Weroniki trudno jest uznać go za główne kryterium klasyfikujące odrębne typy ikonograficzne św. Weroniki. Wydaje się natomiast, że za takie kryterium ustalające odrębne typy ikonograficzne, niosące nowe treści ideowe, uznać można wzajemne proporcje św. Weroniki i trzymanej przez nią chusty. Scharakteryzowane powyżej typy dla przejrzystości dalszej analizy nazwę typ A (chusta zajmuje ok. 1/4 postaci św. Weroniki) oraz B (chusta stanowi ok. $3 / 4$ postaci).

Przedstawienie toruńskie nie mieści się w typie A. Wydaje się, iż artysta nie wykorzystał tego wariantu z powodu silnego eksponowania przede wszystkim postaci Świętej. Przykładem przedstawienia, w którym zastosowano typ A, jest ołtarz z Bakowa - chusta jest niejako tylko atrybutem identyfikującym Świętą (Bąków, kościół par. Wnie- 
bowzięcia Panny Marii, tryptyk, skrzydło lewe, awers, Święte Niewiasty, przed 1380$)^{26}$.

Toruńskie malowidło wykazuje szczególne podobieństwo do przedstawień typu B, które eksponują wyraźnie chustę w rękach Świętej. Wspomniane wyżej przykłady przedstawień typu B stwarzają wrażenie, iż Weronika spełnia funkcję podobna jak „trzymacz” prezentujący herb (np. Anioł podtrzyujący herb Torunia). Na wizerunku z kościoła św. Mikołaja [il. 5] ${ }^{27}$ funkcję tę wzmacnia dodatkowo wskazywanie przez Weronikę oblicza Chrystusa. Mając na uwadze lokalizację omówionych przedstawień typu B (nisza sakrarium, drzwiczki tabernakulum, wspornik, dekoracja tympanonu) przyjąć można, iż świadomie sięgnięto po określony typ ikonograficzny.

Wśród średniowiecznego materiału ikonograficznego można wskazać takie przedstawienia, które wykazują szczególne podobieństwo typu ikonograficznego z toruńską św. Weronika. Elementami wyróżniającymi toruńskie przedstawienie są dużych rozmiarów chusta, całkowicie od dołu zasłaniająca postać św. Weroniki, oblicze Chrystusa na chuście bez korony cierniowej, sposób trzymania chusty - od tyłu i całymi dłońmi, charakterystyczne trójkąty, w jakie układa się trzymana przez Świętą tkanina. Pewne podobieństwo wykazuje grafika z Kroniki Świata Schedla [il. 10]) - dużych rozmiarów, podobna w kształcie chusta. Różnicę stanowią - obecność korony cierniowej u Chrystusa i inne nakrycie głowy św. Weroniki. Pewne elementy zbieżne można wskazać pomiędzy toruńskim przedstawieniem a witrażem z kościoła Bożego Ciała - Duża Chusta, Chrystus bez korony cierniowej [il. 8A]. Na ogół wskazać można bliskość pojedynczych motywów między wizerunkami typu B a toruńskim przedstawieniem, np. zastosowanie nimbu krzyżowego w formie stylizowanych lilii (witraż z Krakowa) lub sposób trzymania chusty (całą ręką i od tyłu np. malowidło w Suszu).

Szczególnie duże podobieństwo do toruńskiego przedstawienia wykazuje tzw. plakietka pielgrzymia z wizerunkiem św. Weroniki ([il. 9] 2. poł. XV w., brąz $55 \times 99 \mathrm{~mm}$, Muzeum Watykańskie). Funkcję określa widoczny w górnej części otwór, dzięki któremu plakietkę przyszywano do płaszcza, kapelusza czy torby pielgrzyma. Tego typu pamiątki były,

\footnotetext{
26 Malarstwo gotyckie w Polsce, Katalog 2004, s. 142, il. 252.

27 Zob. przypis 18.
} 
jak wyżej wspomniano, powszechnie zabierane z Rzymu przez pielgrzymów. Wizerunek na plakietce wykazuje duże podobieństwo do toruńskiego przedstawienia w zakresie chusty zakrywającej od dołu cała postać św. Weroniki, braku korony cierniowej (na głowie Chrystusa), sposobu trzymania chusty przez św. Weronikę. Odmienny nieco jest kształt chusty. Skłon głowy św. Weronki - w toruńskim przedstawieniu na lewo, na plakietce na prawo - stwarza wrażenie, iż wizerunki są wzajemnym lustrzanym odbiciem. Trudno orzec, czy jest to przypadek, czy też świadome zastosowanie skłonu głowy w kierunku prezbiterium i jaki mógłby być związek powyższego z liturgia.

Założyć można, iż istniał wspólny wzór graficzny, powszechnie dostępny w owym czasie w postaci druków ulotnych, który ulegał w przypadku każdego przedstawienia niewielkim modyfikacjom. Wymienione podobne obiekty pozwalają dzięki ikonografii [il. 9] - plakietka pielgrzymia z 2. poł XV w. - potwierdzić czas powstania toruńskiego malowidła na 2. poł XV wieku.

Wśród różnych wizerunków św. Weroniki toruński twórca wybrał wariant, który charakteryzuje się wyeksponowaniem dużych rozmiarów Veraiconu. Jednocześnie wskazać można duże podobieństwo malowidła do plakietki pielgrzymiej z muzeum watykańskiego [il. 9]. Trudno dziś jednoznacznie wykazać, czy te nawiązania artysta uczynił świadomie. Niewattpliwie pewien wizualny przekaz docierał i oddziaływał na odbiorcę. Obrazy umieszczone w przestrzeni kościelnej w szczególny sposób wspomagaja kult. Nasuwa się pytanie, dlaczego wizerunek umieszczono tak wysoko i wybrano typ ikonograficzny eksponujący przede wszystkim chustę.

Veraicon (sam bez Weroniki) często umieszczany jest na wschodniej ścianie w przestrzeni prezbiterium (Toruń kościół św. Jakuba, ok. 1390, Hosin, kościół św.św. Piotra i Pawła, 1300-1350) bądź przy sakrarium² ${ }^{28}$. W tych przypadkach Oblicze Chrystusa odnosi się do akcji liturgii mszy lub miejsca przechowywania Eucharystii, objaśnia tajemnicę transsubstancjacji - Twarz Chrystusa na chuście symbolizuje przemienioną Hostię na korporale. Umieszczenie malowidła toruńskiego na wschodniej ścianie nawy południowej, mimo że poza bezpośrednia przestrzenia prezbiterium - litur-

${ }_{28}$ Problem treści ideowych Veraiconu zob. Turska, op.cit., s. 60-61, il. 2, il. 8. 
gii ołtarza, również mogło nieść przekaz o tajemnicy Eucharystii. Weronika trzyma w szeroko rozpostartych ramionach chustę dominująca w kompozycji rozmiarami jak gdyby z apelem o czczenie Boga - Chrystusa, dostępnego docześnie w Eucharystii. Jednocześnie postać św. Weroniki, świadka Pasji Chrystusa, wnosi dodatkowe akcenty przypomnienia o Męce. Tego typu obrazowa zachęta do rozważania tajemnicy Boga w Eucharystii, kontemplacji Pasji, charakterystyczna jest dla pobożności i kultu Sakramentu w XV wieku. W wieku tym obserwować można szczególne narastanie kultu sakramentalnego poza liturgia Mszy św. i związane z nim zapotrzebowanie wiernych na jego różne formy (wystawienia, procesje, różne formy adoracji). Ważne jest, iż od XIV wieku, a szczególnie w XV wieku do propagowania kultu Eucharystii czynnie włączają się świeccy ${ }^{29}$. Powstaja liczne Bractwa Bożego Ciała - np. w Toruniu w 1394 roku $^{30}$. Działalność bractw potwierdzała, iż wśród świeckich istniała potrzeba angażowania się i uczestniczenia w kulcie Sakramentu. Kościół starał się sprostać temu zapotrzebowaniu poprzez wyznaczanie i wyróżnianie miejsc w przestrzeni sakralnej świątyni, umożliwiających adorację i przypominających o Eucharystii. Do dekoracji tych miejsc wykorzystywano także ikonografię św. Weroniki. Przykłady kościoła św. Mikołaja w Marktbreit (dekoracja sakrarium ściennego) i obrazu Mistrza św. Weroniki (dekoracja drzwi tabernakulum) wskazują, iż sięgano w takim przypadku do wizerunku typu B. W kościele św. Janów również starano się sprostać zapotrzebowaniu na kult Eucharystii - w nawie północnej pierwsza kaplica od wschodu była już w poł. XIV w. kaplicą Bożego Ciała. W nawie południowej od 2. połowy XV wieku wprowadzono wizerunek św. Weroniki, także typu B (eksponuje chustę). Zapewne istniejące poniżej malowidła ze św. Weronika, XIX-wieczne obmalowanie baldachimowej konstrukcji jest dowodem na istniejące tam w średniowieczu sakrarium wieżyczkowe.

29 P. Browe, Die Verehrung der Eucharystie im Mittelalter, München 1933, s. 89-181; idem, Die Eucharistie im Mittelalter, Berlin 2008, s. 381-509; Hans Caspary Kult und Aufbewahrung der Eucharystie In Italien von dem Tridentium, "Archiv fur Liturgiewissenschaft" 1965, 9, 1, s. 102 -130; Heike, Schlie, Bilder des Corpus Christi. Sakramentaler Realismus von Jan van Eyck bis Hieronymus Bosch, 2002

30 M. Woźniak, Ottarze w przestrzeni liturgicznej kościoła Świętojańskiego w Toruniu, [w:] Drieje i skarby kościoła Świętojańskiego w Toruniu, red. K. Kluczwajd, M. Woźniak, Toruń 2002, s. 273-294, szczególnie s. 277-279. 
Poza przestrzenią bezpośrednio dostępną dla wiernych w zakrystii Kościoła (miejsce przechowywania Eucharystii) znajduja się rzeźby zawierające eucharystyczny program ikonologiczny ${ }^{31}$. Dalsze badania dotyczące kontekstu innych malowideł z kościoła św.św. Janów oraz topografii tej światyni być może pozwolą ujawnić inne funkcje wizerunku św. Weroniki, np. związane $z$ procesjami teoforycznymi.

Duże podobieństwo wizerunku św. Weroniki z kościoła św. Janów do plakietki pielgrzymiej z muzeum watykańskiego [il. 9] można wiązać z próbą legitymizacji toruńskiego wizerunku poprzez nawiązanie do rzymskiej relikwii. Legitymizacja ta służyć mogła intensywniejszemu oddziaływaniu na wiernych. Przypomnieć należy, iż relikwia rzymska opatrzona była licznymi odpustami dla tych, którzy modlą się do niej w Rzymie bądź modla się przed kopią oryginału. Zarówno dla tych, którzy odbyli pielgrzymkę do Rzymu, jak i pozostałych wiernych wizerunek powielający rzymską relikwię był gwarantem uzyskania odpustu.

Zwrócić należy uwagę, iż liczni toruńscy kupcy i handlarze tkanin mogli być w szczególny sposób zainteresowani modlitwą do patronki handlarzy tkanin. Ważna też była rola św. Weroniki jako chroniącej przed nagła śmiercia.

Profesor E. Pilecka definiuje sposób dekoracji przestrzeni sacrum i laicum kościoła św. Janów - prezbiterium - sacrum zawiera program chrystologiczno-eklezjalny, natomiast laicum - przestrzeń nawowa bardziej odpowiada dążeniom ideowym, potrzebom i gustom artystycznym wiernych, nie rezygnując z programu ${ }^{32}$. Przebudowa korpusu nawowego w 2. połowie XV wieku uwzględniała ambicję mieszczan poprzez program architektoniczny, który sprawiał, iź świątynia miała być odczytywana jako „zamek władzy”. W tym kontekście logiczne wydaje się umieszczenie trzymanego przez Weronikę „Prawdziwego Wizerunku Chrystusa” jako palladionu, chroniącego miasto. Doświadczenia wojny trzynastoletniej mogły skłaniać mieszczaństwo toruńskie do odwołania się do ochrony miasta przez Siłę Najwyższa. Dlaczego wybrano Veraicon z św. Weronika? Wydaje się, że przy całej

\footnotetext{
31 E. Pilecka, Kościót pw. św. Jana Chrzciciela i sw. Jana Ewangelisty w Toruniu w okeresie średniowiecza jako wizualizacja świadomości spotecznej, [w:] Drieje i skarby..., s. 119-176, s. 163-168.

32 Ibidem, s. 119-176.
} 
wspominanej różnorodności przedstawień typów ikonograficznych „,wizerunku uczynionego nie ręką ludzką" św. Weronika, jako pierwsza właścicielka, dawała gwarancję, iż wierni stoja przed prawdziwym wizerunkiem oblicza Chrystusa, biorącego ich w obronę.

\section{Podsumowanie}

Średniowieczne przedstawienia wizerunków św. Weroniki nasycone były wieloma treściami, związanymi zarówno z otoczoną kultem relikwią, jak i legendą i kultem Świętej. Poszczególne warianty ikonograficzne eksponują wybrane aspekty ideowe. Twórca (pod wpływem zleceniodawcy?) toruńskiego przedstawienia św. Weroniki wybierając określony typ ikonograficzny, w wysokim stopniu wykorzystał te możliwości.

W przestrzeni przeznaczonej dla laikatu w 2. połowie XV wieku pojawił się wizerunek św. Weroniki, który zawierał przenikające się płaszczyzny znaczeń religijnych (aspekt eucharystyczny, relikwii, palladionu). Można go uznać za jeszcze jeden element dopełniajacy, który w ikonografii tej przestrzeni uwzględnia i odpowiada na potrzeby religijne, a także w pewnym stopniu polityczne mieszczaństwa tego okresu.

\section{Summary}

\section{Iconography of St. Veronica}

\section{- ideological aspects and functions of depictions}

The starting point for the analysis of medieval iconography of St. Veronica is her depiction (wall painting, 3rd quarter of the 15th century) in the Cathedral Basilica of St. John the Baptist and St. John the Evangelist in Torun. The painting represents St. Veronica standing, holding the veil with the likeness of the face of Christ (Vera Icon); it can be found on the eastern wall of the southern nave, on the right of the presbytery. This article is an attempt to decode ideological aspects and functions of the painting in the context of the times and the circumstances of its creation: the religiosity of the inhabitants of Torun in that period, as well as historical events. A classification and analysis of various iconographic types of St. Veronica in medieval depictions is presented. The article also in- 
dicates a group of depictions, as well as specific works of art, to which the wall painting refers. It was established that the author of the Torun painting, out of a number of possible iconographic types of St. Veronica, chose the one that encompassed interlinked levels of religious meaning. Placed in a space accessible for the laity, the painting reflected religious and, to an extent, also political needs of the middle class of that period. 


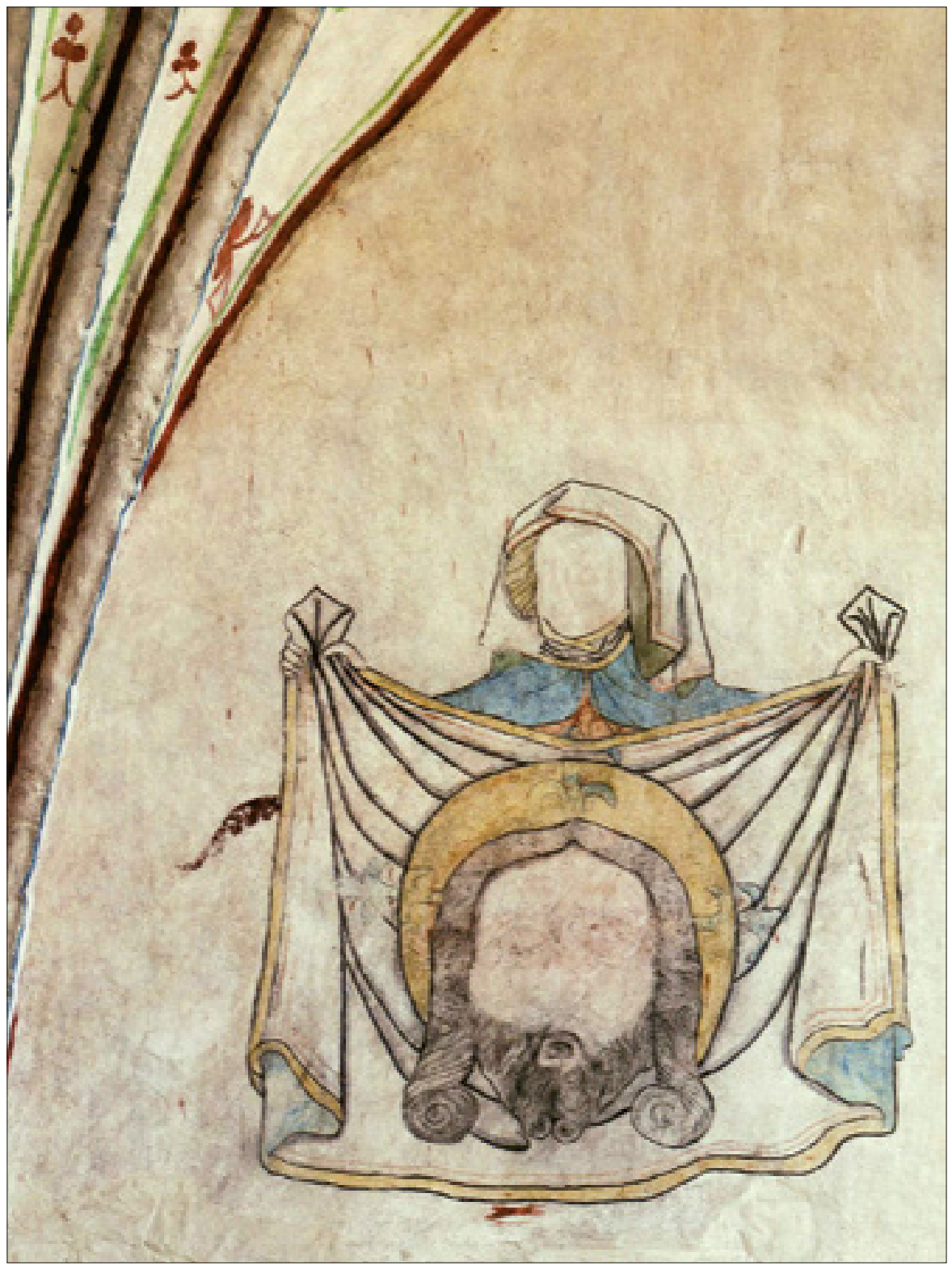

Il. 1. Malowidło ścienne, Święta Weronika trzymająca chustę z wizerunkiem Chrystusa, Toruń kościół Świętojański, 3 ćw. XV w., il za Opus temporis: 2013, il 27 

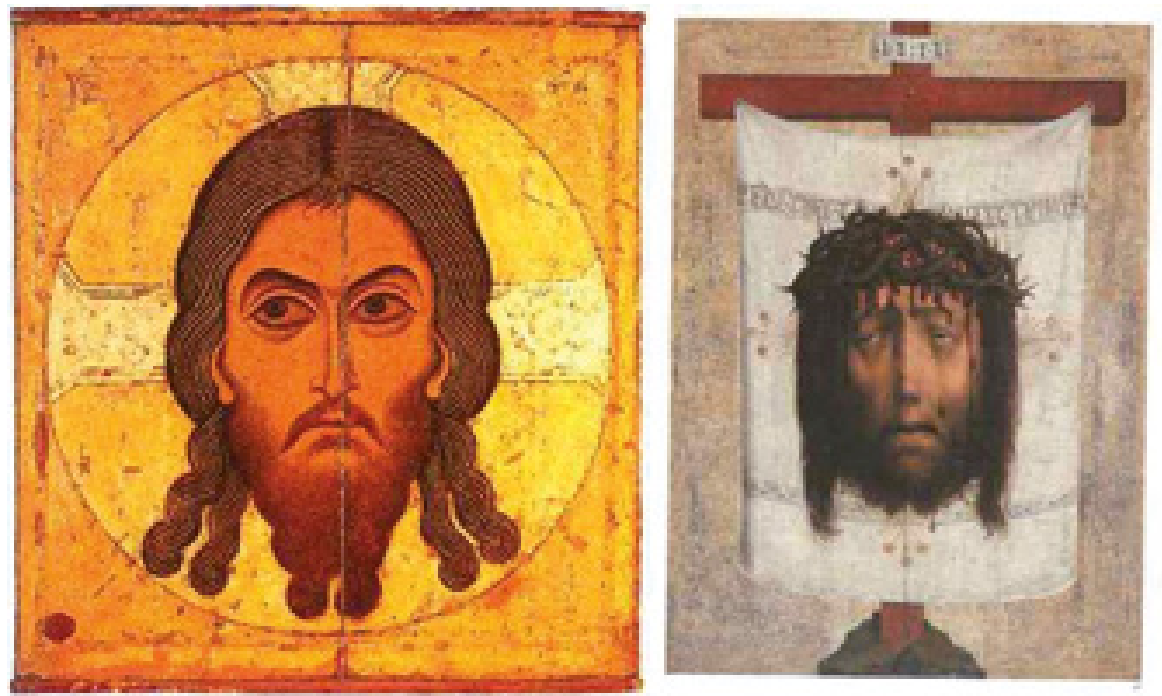

Il. 2. A. Ikona, Mandylion z Nowgorodu, k. XII w., Moskwa, Galeria Tretiakowska, http:// www.icon-art.info/masterpiece.php?lng=de\&mst_id=141; dostęp 5.02.2015 B. Obraz na desce, Vericon z Legnicy, ok.1450 r., Wrocław, Muzeum Narodowe Fot. za Zimecka 2003, il. 47 


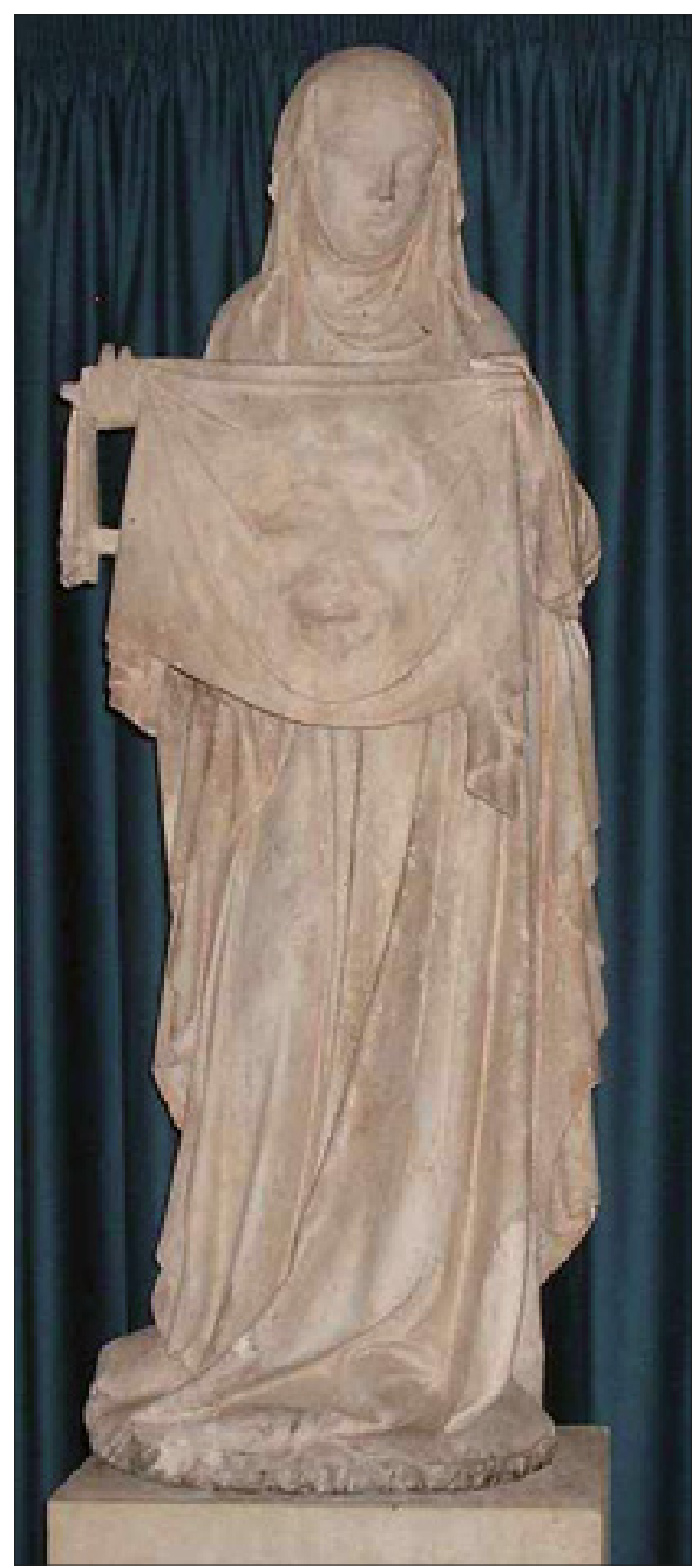

Il. 3. Rzeźba , Święta Weronika, ok.1310,kolegiata Notre- Dame d Ecouis, (Eure) Francja il, za http://commons.wikimedia.org/wiki/File:Ecouis_sainte_veronique.jpg, dostęp 1.03.2015 


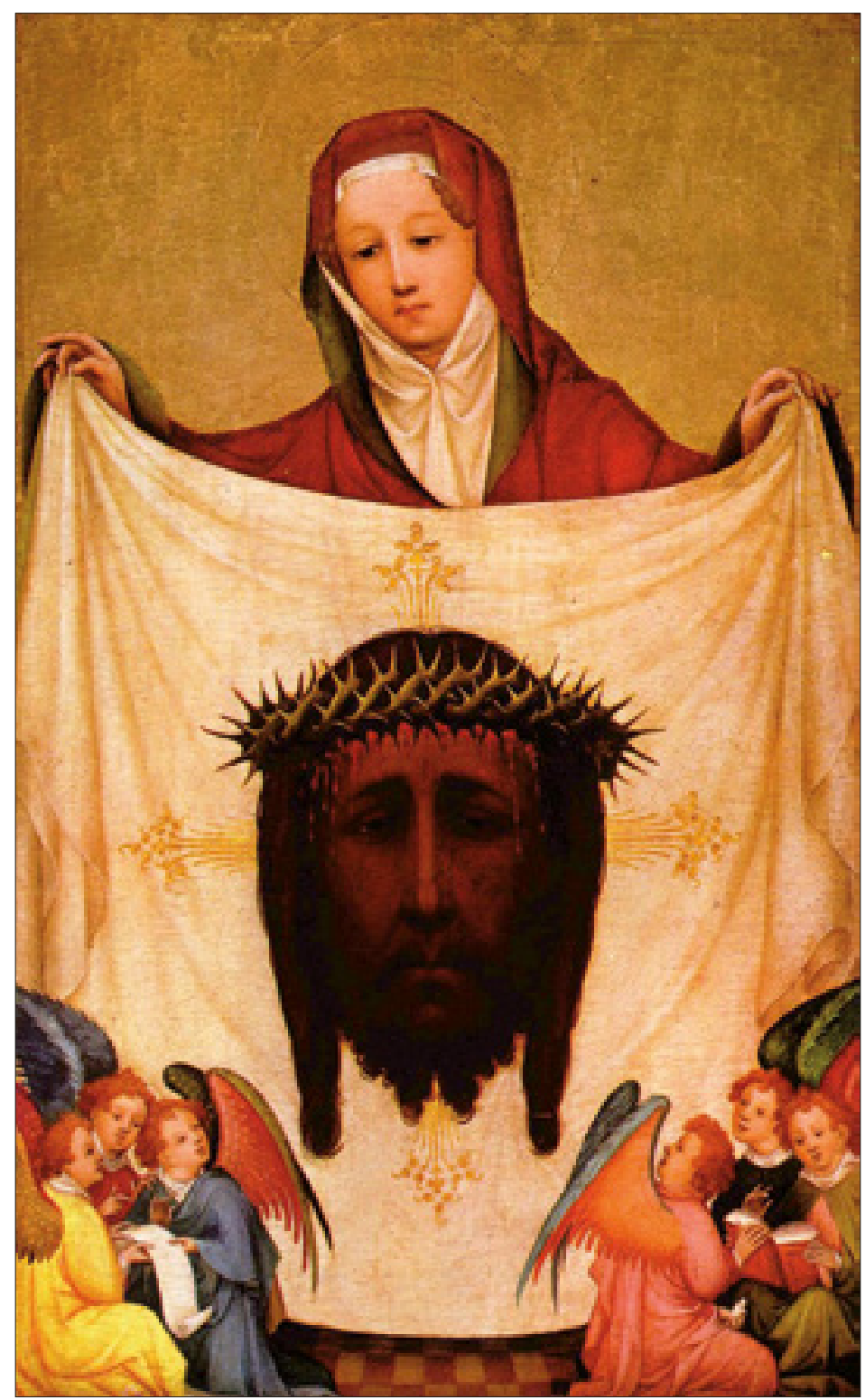

Il. 4. Obraz, Święta Weronika, Mistrz Św.Weroniki,ok.1420, München, za https://commons. wikimedia.org/wiki/File:Meister_der_Heiligen_Veronika_-_Hl._Veronika_mit_dem_Schwei\%C3\%9Ftuch_Christi_-_Alte_Pinakothek.jpg\#/media/File:Meister_der_Heiligen_Veronika_-_Hl._Veronika_mit_dem_Schwei\%C3\%9Ftuch_Christi_-_Alte_Pinakothek.jpg, dostęp 20.02.2015 


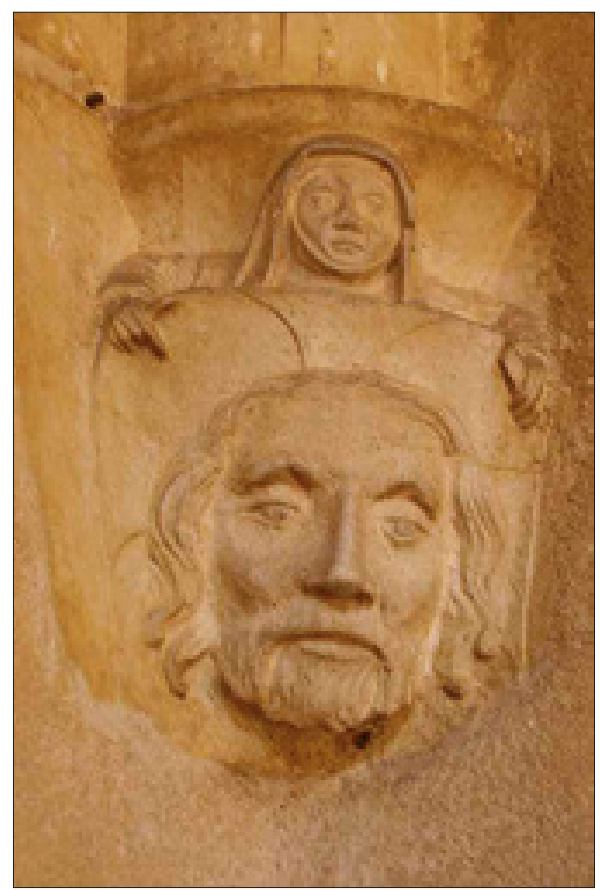

Il. 5. Płaskorzeźba, Święta Weronika, pocz. XVI w ,kościół klasztorny Św. Mikołaja,Brou, Francja,http://commons.wikimedia.org/wiki/File:Corbel_Brou_3.jpg\#mediaviewer/File:Corbel_Brou_3.jpg, Remi Mathis, dostęp 27.01.2015 


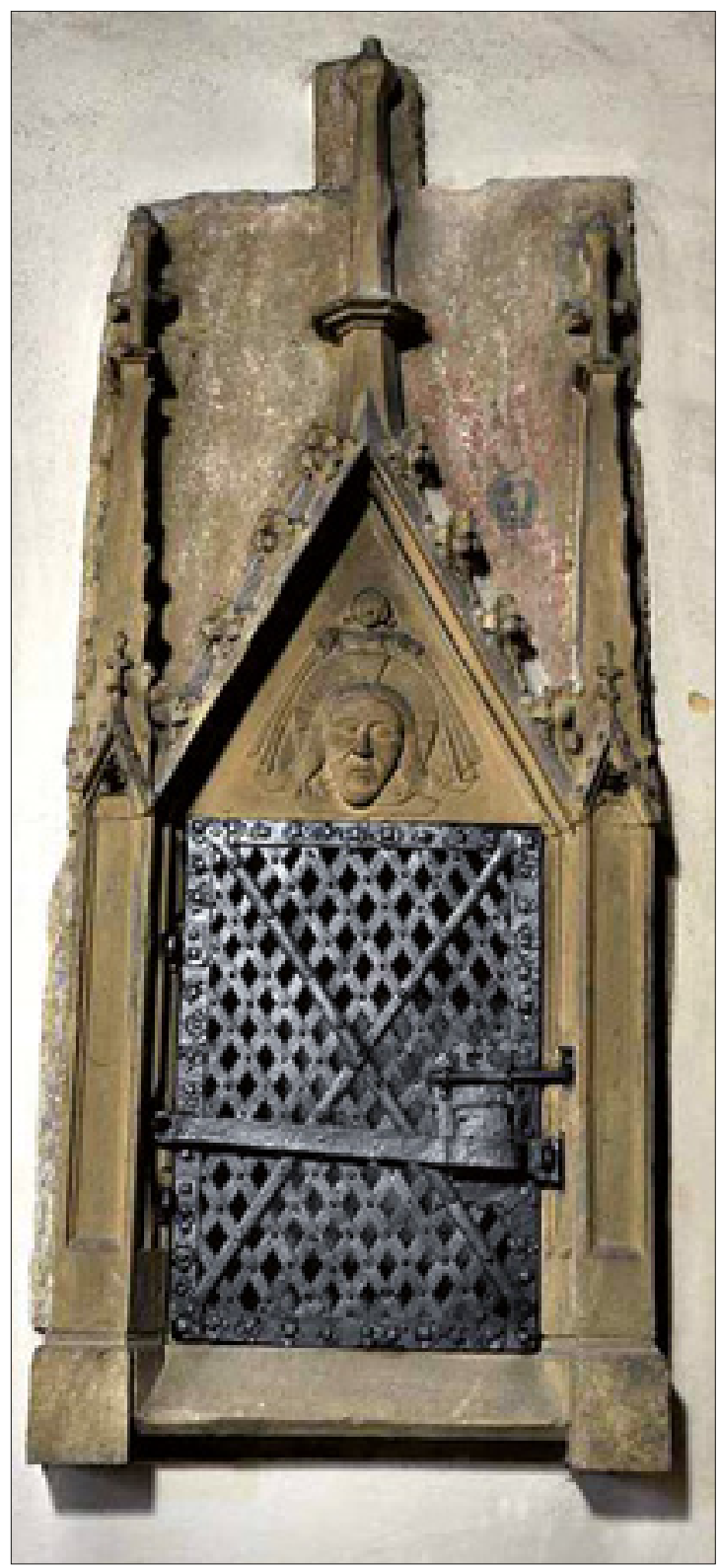

Il. 6. Płaskorzeźba, Święta Weronika, sakrarium ścienne, kościół, St.Nikolai w Marktbreit, Niemcy, ok. 1400. http://commons.wikimedia.org/wiki/Category:St._Nikolai_\%28Marktbreit $\% 29 \# /$ media/File:Marktbreit_St_Nikolai_Wandtabernakel.jpg, Andreas Praefcke, dostęp 19.01.2015 


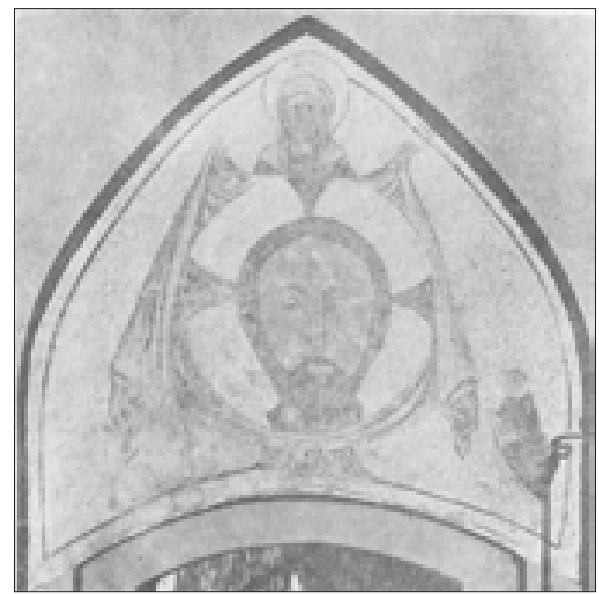

Il. 7. Malowidło ścienne, Święta Weronika, kościół farny, Susz, ok. 1400, il. za Domasłowski 1984, il. 183 


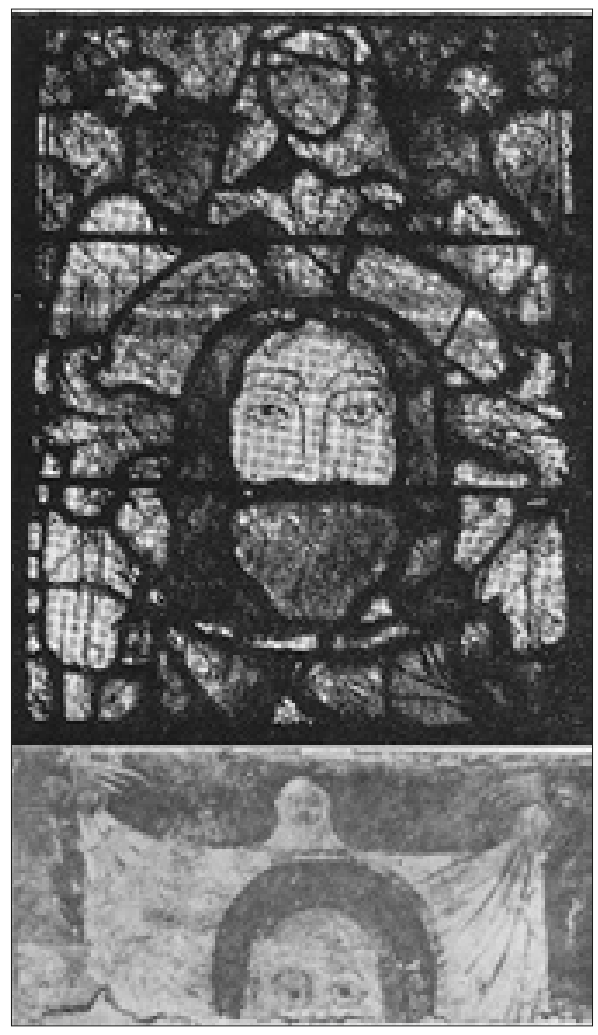

Il. 8. A. Witraż, Święta Weronika, Kościół Bożego Ciała, Kraków, 1420-1430, il. za KZSwP T.IV, cz. 4,1,1987, il. 9256

B. Malowidło ścienne, Święta Weronika, kościół farny, Orneta,3 ćw. XV w. il za Domasłowski 1984, il. 205 


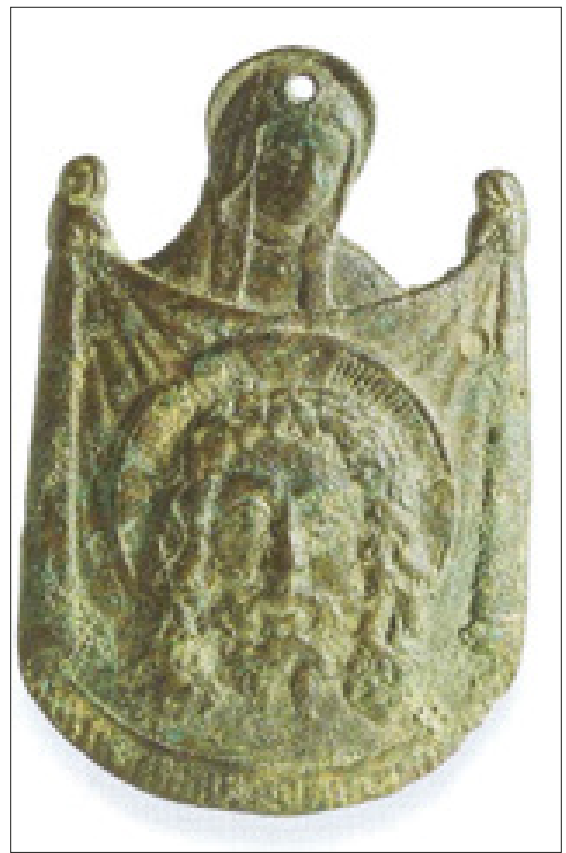

Il. 9. Plakietka pielgrzymia, Święta Weronika, brąz, Watykan, 2. poł. XV w., il. za Morello, Wolf 2000, il. 124

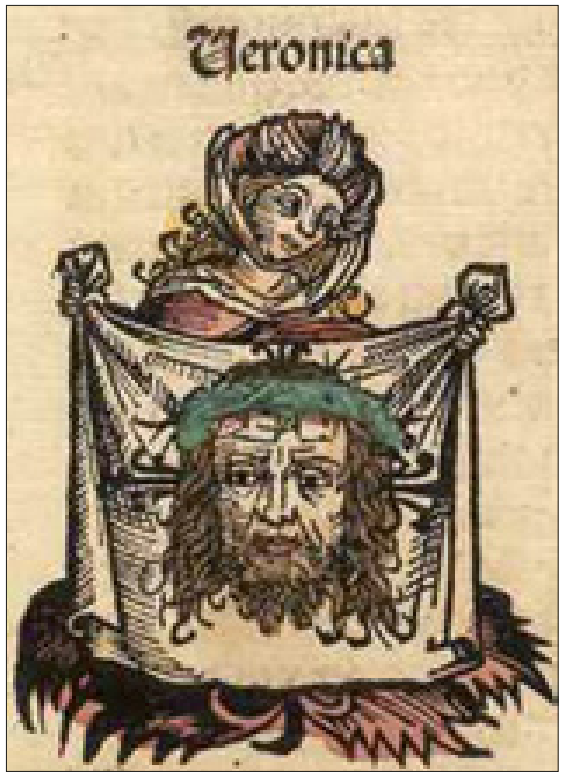

Il. 10. Miniatura w Kronice Świata Schedla Święta Weronika, Nürnberg, Niemcy K.XV w., http://commons.wikimedia.org/wiki/File:Nuremberg_chronicles_f_097r_1.png dostęp 15.02.2015 


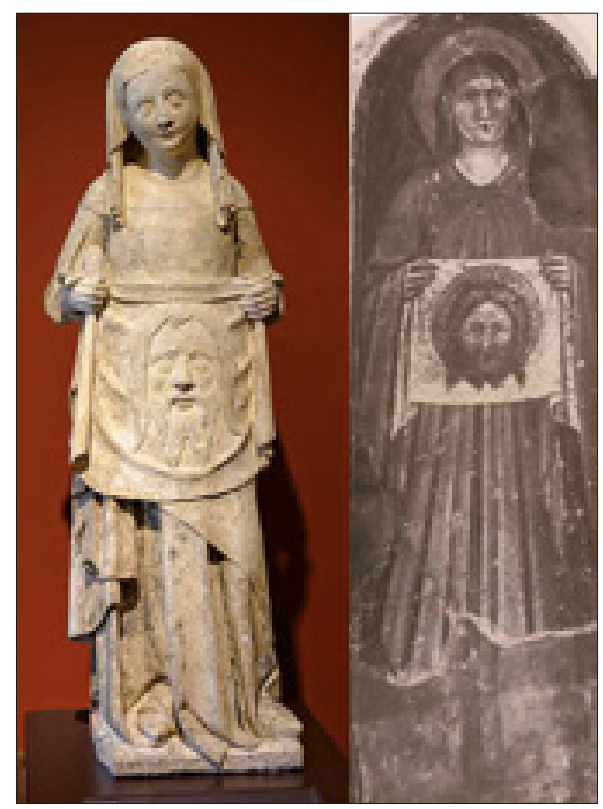

Il. 11. A. Rzeźba, Święta Weronika Dijon Musée des beaux arts, XIV w., Francja, François de Dijon, Sainte Véronique, pierre avec des traces de polychromie. Bourgogne milieu du XIV eme siècle. Musée des beaux arts de Dijon (Côte d'Or, France).

http://commons.wikimedia.org/wiki/File:Sainte_V\% $\% 3 \%$ A9ronique-MBA_Dijon.jpg, dostęp 1.02.2015

B. Obraz, Święta Weronika, szkoła Tomasso da Modena, Treviso S. Lucia, ok. 1350, il. za Kaftal 1978, il. 1346 